\title{
The 2009 stratospheric major warming described from synergistic use of BASCOE water vapour analyses and MLS observations
}

\author{
W. A. Lahoz ${ }^{1,2}$, Q. Errera $^{3}$, S. Viscardy ${ }^{3}$, and G. L. Manney ${ }^{4,5}$ \\ ${ }^{1}$ Norsk Institutt for Luftforskning, NILU, Norway \\ ${ }^{2}$ CNRM-GAME, URA1357, Météo-France and CNRS, Toulouse, France \\ ${ }^{3}$ Institut d'Aéronomie Spatiale de Belgique, BIRA-IASB, Belgium \\ ${ }^{4}$ Jet Propulsion Laboratory, California Institute of Technology, Pasadena, CA, USA \\ ${ }^{5} \mathrm{New}$ Mexico Institute of Mining and Technology, NM, USA
}

Received: 8 September 2010 - Published in Atmos. Chem. Phys. Discuss.: 21 October 2010

Revised: 12 May 2011 - Accepted: 18 May 2011 - Published: 20 May 2011

\begin{abstract}
The record-breaking major stratospheric warming of northern winter 2009 (January-February) is studied using BASCOE (Belgian Assimilation System for Chemical ObsErvation) stratospheric water vapour analyses and MLS (Microwave Limb Sounder) water vapour observations, together with meteorological data from the European Centre for Medium-Range Weather Forecasts (ECMWF) and potential vorticity (PV) derived from ECMWF meteorological data. We focus on the interaction between the cyclonic wintertime stratospheric polar vortex and subsidiary anticyclonic stratospheric circulations during the build-up, peak and aftermath of the major warming. We show dynamical consistency between the water vapour analysed fields and the meteorological and PV fields. Using various approaches, we use the analysed water vapour fields to estimate descent in the polar vortex during this period of between $\sim 0.5 \mathrm{~km} \mathrm{day}^{-1}$ and $\sim 0.7 \mathrm{~km} \mathrm{day}^{-1}$. New results include the analysis of water vapour during the major warming and demonstration of the benefit of assimilating MLS satellite data into the BASCOE model.
\end{abstract}

\section{Introduction}

The main feature of the wintertime stratosphere is a strong cyclonic polar vortex that organizes the stratospheric flow; anticyclonic circulations are also commonly present (Lahoz et al., 2009 and references therein). The Arctic and Antarctic winter stratosphere can be described in terms of vortex inter-

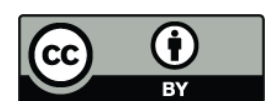

Correspondence to: W. A. Lahoz (wal@nilu.no) actions between a dominant cyclonic polar vortex and one or more subsidiary anticyclones. These wintertime anticyclones can be: (i) quasi-stationary, e.g., the Aleutian High in Arctic winter (Lahoz et al., 1994; Harvey et al., 2002); a climatological anticyclone to the South of Australia in late Antarctic winter (Mechoso et al., 1988; Lahoz et al., 1996, 2006; Harvey et al., 2002, 2004); or (ii) travelling, e.g., eastward travelling anticyclones in mid Antarctic winter, vortex mergers during Arctic and Antarctic winter (Lahoz et al., 1996; Manney et al., 2005).

A particularly interesting dynamical event in the Arctic wintertime stratosphere is the major stratospheric warming (see, e.g., Charlton and Polvani, 2007). These events dramatically disrupt the typical wintertime circulation of the stratosphere. They can also affect tropospheric weather patterns (e.g. Baldwin and Dunkerton, 2001). Climate change induced changes in the frequency and characteristics of major stratospheric warmings are expected owing to changes in the Brewer-Dobson circulation; such changes will in turn impact stratospheric ozone loss and recovery, and tropospheric climate (e.g. WMO, 2007; Charlton-Perez et al., 2008). Major warmings can be classified as vortex displacement (also wavenumber-1) or vortex split (also wavenumber-2) events. During these events the polar vortex is strongly disrupted, and in the mid stratosphere (e.g. $10 \mathrm{hPa}$ ) polar temperatures increase dramatically over a few days and zonal mean zonal winds reverse sign from westerly to easterly at latitudes poleward of $60^{\circ} \mathrm{N}$.

The major warming that took place during JanuaryFebruary 2009 was the strongest and most prolonged on record (Labitzke and Kunze, 2009; Manney et al., 2009b); it was a vortex-split event, and major stratospheric warming criteria were met on 24 January: easterly zonally averaged

Published by Copernicus Publications on behalf of the European Geosciences Union. 
zonal winds at $10 \mathrm{hPa}$ and $60^{\circ} \mathrm{N}$, and temperature gradient reversal poleward of $60^{\circ} \mathrm{N}$ at $10 \mathrm{hPa}$. Only in the past few years have sufficient data been available to thoroughly study the dynamics and transport during a major stratospheric warming throughout the upper troposphere to the mesosphere - see Manney et al. (2009b) and references therein for details. These papers have studied major stratospheric warmings based on observations of tracers, meteorological analyses of geopotential height, temperature and horizontal winds, and fields of potential vorticity (PV) derived from meteorological analyses. However, to our knowledge, major warmings have not been studied hitherto using analyses of stratospheric water vapour produced using data assimilation, chiefly because it is only recently that such analyses have started to become available and be evaluated (Juckes, 2007; Lahoz et al., 2007a, b; McCormack et al., 2008; Eckermann et al., 2009; Thornton et al., 2009). The lack of operational observations of stratospheric water vapour for NWP (Numerical Weather Prediction) centres to assimilate contributes to the scarcity of published research on stratospheric water vapour analyses.

We use stratospheric water vapour analyses and observations synergistically to study the spatial characteristics and temporal evolution of the cyclonic and anticyclonic circulations prevalent during the major stratospheric warming that took place during January-February 2009. Water vapour analyses are from the state-of-the-art BASCOE (Belgian Assimilation System for Chemical ObsErvation) chemical data assimilation system (Errera and Fonteyn, 2001; Errera et al., 2008; Viscardy et al., 2010). Water vapour observations are from MLS, the Microwave Limb Sounder (Lambert et al., 2007). Meteorological data (geopotential height fields, PV fields) are from the ERA Interim analyses (http://www.ecmwf.int/research/era/do/get/index) provided by the European Centre for Medium-Range Weather Forecasts, ECMWF. These data are described in, e.g., Simmons et al. (2005).

Data used in this paper are analysed using a 1-D alongorbit picture (see Lahoz et al., 2009, and references therein) and a 2-D equivalent latitude-theta picture, where theta is potential temperature (see Manney et al., 2009b, and references therein). Data are also analysed with 2-D latitude-longitude maps at selected pressure or theta levels. The geometry of the 1-D picture provides a physically meaningful (coordinate independent) pole-centred picture of the stratosphere and mesosphere. An advantage of the pole-centred picture is that it retains the information content in the data without the blurring effect of gridding by interpolation between viewing tracks and averaging along latitude circles. The 2-D equivalent latitude-theta picture involves some interpolation and averaging, but since the averaging is done along PV contours, preserves much of the vortex-centred viewpoint; this picture provides information on the roles of quasi-horizontal transport and vertical transport in determining tracer distributions.
It can be advantageous to fill in the observational gaps between the viewing tracks, for example, to estimate ozone loss, and compute vortex-averaged quantities of tracers that can be used to estimate vertical transport (e.g. identified by descent of tracer isopleths). An objective method to fill in the observational gaps is data assimilation (see, e.g., Kalnay, 2003; Lahoz et al., 2010). This combines the information from the observations and the a priori knowledge of the state of the atmosphere (and their associated error covariances), the latter typically embodied in a numerical model. Data assimilation has been used successfully to produce analyses of stratospheric constituents such as ozone and water vapour; evaluate observations of stratospheric chemical constituents; and evaluate chemical models. Papers describing this work include (the list is not exhaustive) Fisher and Lary (1995), Khattatov et al. (2000), Errera and Fonteyn (2001), Dethof and Hólm (2004), Geer et al. (2006, 2007), Lahoz et al. (2007a, b), Jackson (2007), McCormack et al. (2008), Eckermann et al. (2009), Thornton et al. (2009) and Lahoz and Errera (2010). The review by Lahoz et al. (2007a) includes a comprehensive list of references. Data assimilation has also been used to estimate stratospheric ozone loss (see, e.g., Jackson and Orsolini, 2008; El Amraoui et al., 2008; Rösevall et al., 2008; the World Meteorological Office, WMO, website, http://www.wmo.int/pages/prof/arep/ gaw/ozone/index.html).

Section 2 describes the BASCOE chemical data assimilation system and the MLS water vapour data. Sections 3-4 describe the evolution of the stratosphere for selected dates during the January-February 2009 period, spanning the buildup, peak and aftermath of the major warming. Section 3 provides a picture of the meteorology from ECMWF data. Section 4 provides, first, a comparison of 2-D water vapour analyses and 2-D gridded MLS water vapour observations, with a focus on the benefit of data assimilation compared to observations (Sect. 4.1); and second, a combined 2-D maps/1-D along-orbit pole-centred picture of the dynamics, looking at water vapour observations and analyses, and PV fields, with a focus on consistency of the different dynamical pictures of the major warming (Sect. 4.2). The MLS orbits considered in Sect. 4.2 are chosen to cut through the cyclonic and anticyclonic circulations present during the period of the major warming. Section 5 discusses vortex descent rates computed using various approaches. Section 6 provides conclusions.

\section{BASCOE data assimilation system}

\subsection{BASCOE set-up}

BASCOE is a 4D-Var (4-D variational) assimilation system described in Errera et al. (2008). Its performance for various analysed species is described in several papers (Errera and Fonteyn, 2001; Geer et al., 2006; Lahoz et al., 2007b; Errera et al., 2008; Thornton et al., 2009; Viscardy et al., 2010). The 
BASCOE system is based on a 3-D CTM (chemistry transport model) dedicated to stratospheric chemistry processes; it uses a time step of $30 \mathrm{~min}$. In this study, the CTM is driven by ECMWF ERA Interim analyses of winds and temperatures on a subset of 37 of the 60 ECMWF model levels, from the surface to $0.1 \mathrm{hPa}$ with a horizontal resolution set to $3.75^{\circ}$ longitude by $2.5^{\circ}$ latitude. Hence, the horizontal resolution corresponds to a maximum of $\sim 415 \mathrm{~km}$ in longitude and a maximum of $\sim 277 \mathrm{~km}$ in latitude. The vertical resolution is $\sim 1.5 \mathrm{~km}$ in the mid stratosphere.

The BASCOE CTM includes a parametrization to take into account the effect of Polar Stratospheric Clouds (PSCs) - see Errera et al. (2008) for details. Although the BASCOE model extends down to the surface, it does not include any tropospheric processes. Below the tropopause, MLS water vapour profiles are not assimilated as the BASCOE model fixes the tropospheric water vapour field to that of the ECMWF ERA Interim analyses. The thermal tropopause is calculated in the BASCOE model using ECMWF ERA Interim pressure and temperature fields mapped to the BASCOE horizontal resolution.

For the experiments described in this paper, the BASCOE system assimilates over a $24-\mathrm{h}$ window various MLS version v2.2 species within their useful vertical range (see Table 1.1 in the v2.2 Data Quality Document, Livesey et al., 2007). These species are: $\mathrm{H}_{2} \mathrm{O}, \mathrm{ClO}, \mathrm{HCl}, \mathrm{HNO}_{3}, \mathrm{~N}_{2} \mathrm{O}, \mathrm{O}_{3}$ and $\mathrm{OH}$. In particular, water vapour is a control variable in the BASCOE 4D-Var system and its background errors are diagonal (i.e., all off-diagonal elements are set to zero) with a standard deviation equal to $20 \%$ of the background humidity field. $\mathrm{CO}$ and $\mathrm{N}_{2} \mathrm{O}$ observations were used by Manney et al. (2009b) to study the major warming of 2009. This was possible by considering averages of these observations. In data assimilation observations are considered individually, and the relatively large observation error bars of MLS CO and $\mathrm{N}_{2} \mathrm{O}$ compared to the BASCOE background errors - for $\mathrm{CO}$ over the whole vertical domain of BASCOE (Pumphrey et al., 2007), for $\mathrm{N}_{2} \mathrm{O}$ above $10 \mathrm{hPa}$ (Lambert et al., 2007) - mean their weight in the analyses is insignificant. We thus exclude these species from this study. Instead, we use the MLS water vapour observations and the BASCOE water vapour analyses. Their validation is discussed in Sects. 2.2 and 2.3 , respectively.

\subsection{Validation of MLS water vapour observations}

The MLS v2.2 water vapour data have been validated by Lambert et al. (2007). Single-profile precision is $\sim 0.2-0.3$ parts per million by volume, ppmv (4-9\%) and vertical resolution is $\sim 3-4 \mathrm{~km}$ in the stratosphere. Precision and vertical resolution gets worse with increasing height above the stratopause. Over the pressure range $0.1 \mathrm{hPa}-0.01 \mathrm{hPa}$ precision degrades from $\sim 0.4 \mathrm{ppmv}$ to $\sim 1.1 \mathrm{ppmv}$ ( $6 \%$ to $34 \%$ ) and vertical resolution degrades to $\sim 12-16 \mathrm{~km}$. Accuracy is estimated to be $0.2-0.5 \mathrm{ppmv}(4-11 \%)$ for the pressure range
$68 \mathrm{hPa}-0.01 \mathrm{hPa}$. The scientifically useful range of the data is from $316 \mathrm{hPa}$ to $0.002 \mathrm{hPa}$.

\subsection{Validation of BASCOE water vapour analyses}

The BASCOE stratospheric water vapour analyses have been verified against water vapour data from MLS (a selfconsistency test), and validated against independent water vapour data from the ACE-FTS (Atmospheric Chemistry Experiment - Fourier Transform Spectrometer) instrument (Bernath et al., 2005). Figure 1 shows a comparison between the BASCOE water vapour analyses, and the MLS and ACE-FTS water vapour data, with statistics calculated for the period January-February 2009 and over the latitude range $60^{\circ} \mathrm{N}-90^{\circ} \mathrm{N}$. From Fig. 1, bias differences between BASCOE and MLS are less than $2 \%$ throughout the stratosphere, and bias differences between BASCOE and ACEFTS are less than $5 \%$ throughout the stratosphere. BASCOE is slightly drier than ACE-FTS in the mid to upper stratosphere $(10 \mathrm{hPa}-1 \mathrm{hPa})$, and slightly moister in the lower stratosphere, chiefly around $50 \mathrm{hPa}$. The standard deviation between BASCOE analyses and both MLS and ACE-FTS data (computed about the respective mean, i.e., bias, difference), is typically less than $7 \%$ throughout the stratosphere $(100 \mathrm{hPa}-1 \mathrm{hPa})$, with values being less than $5 \%$ in the mid and upper stratosphere $(10 \mathrm{hPa}-1 \mathrm{hPa})$. The bias and standard deviation between BASCOE and MLS are within the precision of the latter (see Sect. 2.2).

\section{Meteorology}

The evolution of the temperature and zonal winds during the major warming is described in detail in Manney et al. (2009b). To further understand the temporal evolution of the stratosphere before, during and after the major warming, we consider Northern Hemisphere (NH) ECMWF 2-D analysed fields of geopotential height at 12:00 UTC for four dates spanning the period of the major warming: 8, 20, 24 January, and 1 February. We focus on geopotential height fields at $100 \mathrm{hPa}$ (lower stratosphere; right column, Fig. 2), $10 \mathrm{hPa}$ (mid stratosphere; middle column, Fig. 2) and $1 \mathrm{hPa}$ (upper stratosphere; left column, Fig. 2).

MLS orbits are chosen to cut through the cyclonic and anticyclonic circulations present during the period of the major warming (Fig. 2). The starting point of the orbits indicated in Fig. 2 is labelled with a closed circle. These orbits are used in Sect. 4.2 to produce line plots (1-D along orbit picture) comparing water vapour analyses and observations, and PV analyses, at various theta levels spanning the stratosphere. The temporal evolution of the geopotential height fields during the period 8 January-1 February 2009 is described below. Manney et al. (2009b) provides details of the evolution of the geopotential height fields for the period December 2008 March 2009 (see their Fig. 1). 

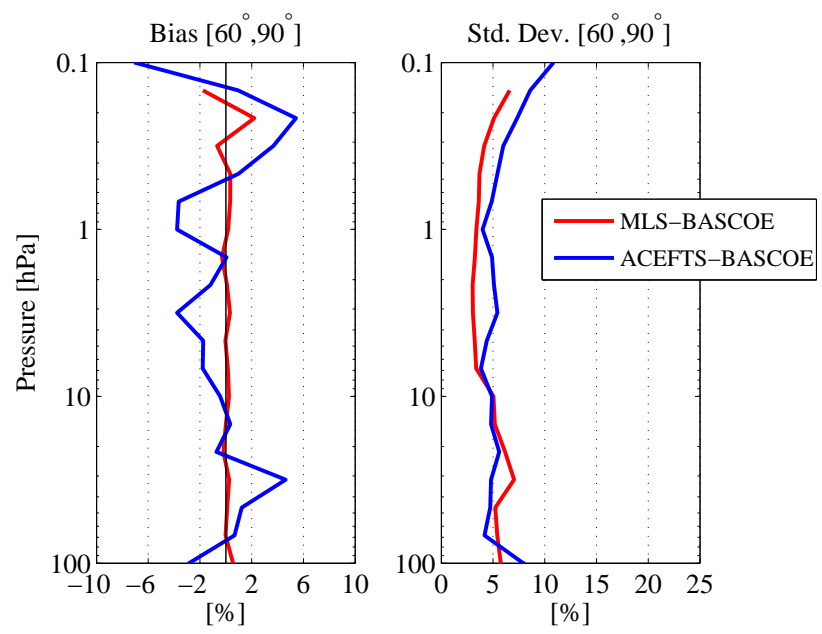

Fig. 1. Bias (left-hand plot) and standard deviation (right-hand plot), as a percentage of the observational data, between BASCOE water vapour analyses and MLS water vapour observations (red line), and between BASCOE water vapour analyses and ACE-FTS water vapour observations (blue line). Statistics are computed for the period January-February 2009 and over $60^{\circ} \mathrm{N}-90^{\circ} \mathrm{N}$ (see text for further details). The $\mathrm{x}$-axis is percent difference (\%); the $\mathrm{y}$ axis is pressure $(\mathrm{hPa})$. Positive values in the bias indicate that the BASCOE analyses are moister than the MLS and ACE-FTS data. To orient the reader, a rough equivalence between pressure levels and isentropic levels is as follows: $50 \mathrm{hPa}(550 \mathrm{~K}) ; 10 \mathrm{hPa}(850 \mathrm{~K})$; $1 \mathrm{hPa}(1900 \mathrm{~K})$.

On 8 January (Fig. 2, top row), the cyclonic polar vortex extends throughout the stratosphere from $100 \mathrm{hPa}$ to $1 \mathrm{hPa}$, with a westward tilt with height. It is roughly axi-symmetric, especially at $10 \mathrm{hPa}$. At $10 \mathrm{hPa}$ and $1 \mathrm{hPa}$ there is an anticyclone over Eastern Siberia. By 20 January (Fig. 2, second row), the polar vortex at $100 \mathrm{hPa}$ comprises two cyclonic circulations. There are two anticyclones at $10 \mathrm{hPa}$ and $1 \mathrm{hPa}$, located over North America and Central Siberia; they contribute to the vortex elongation, and cause it to split at $1 \mathrm{hPa}$ (Manney et al., 2009b, states the vortex split on $\sim 20$ January at $1700 \mathrm{~K}, \sim 2 \mathrm{hPa}$ ). At $10 \mathrm{hPa}$ and $1 \mathrm{hPa}$ the geopotential height pattern is of wavenumber-2 (vortex-split) type, and the anticyclones have strength comparable to that of the cyclonic circulations. At this time the polar vortex is severely distorted in the upper stratosphere.

By 24 January (Fig. 2, third row), the date when major warming criteria are met (Manney et al., 2009b), the anticyclone over the North Pacific at $100 \mathrm{hPa}$ is weaker than on 20 January, and the polar vortex has elongated further. At $10 \mathrm{hPa}$, the anticyclones have moved further toward the North Pole, and split the polar vortex into two circulations located over North America and Central Siberia (Manney et al., $2009 \mathrm{~b}$, states that the vortex split on $\sim 24$ January at $850 \mathrm{~K}$, $\sim 10 \mathrm{hPa}$ ). The circulation (cyclones and anticyclones) exhibits the wavenumber- 2 pattern of a warming of the vortex-
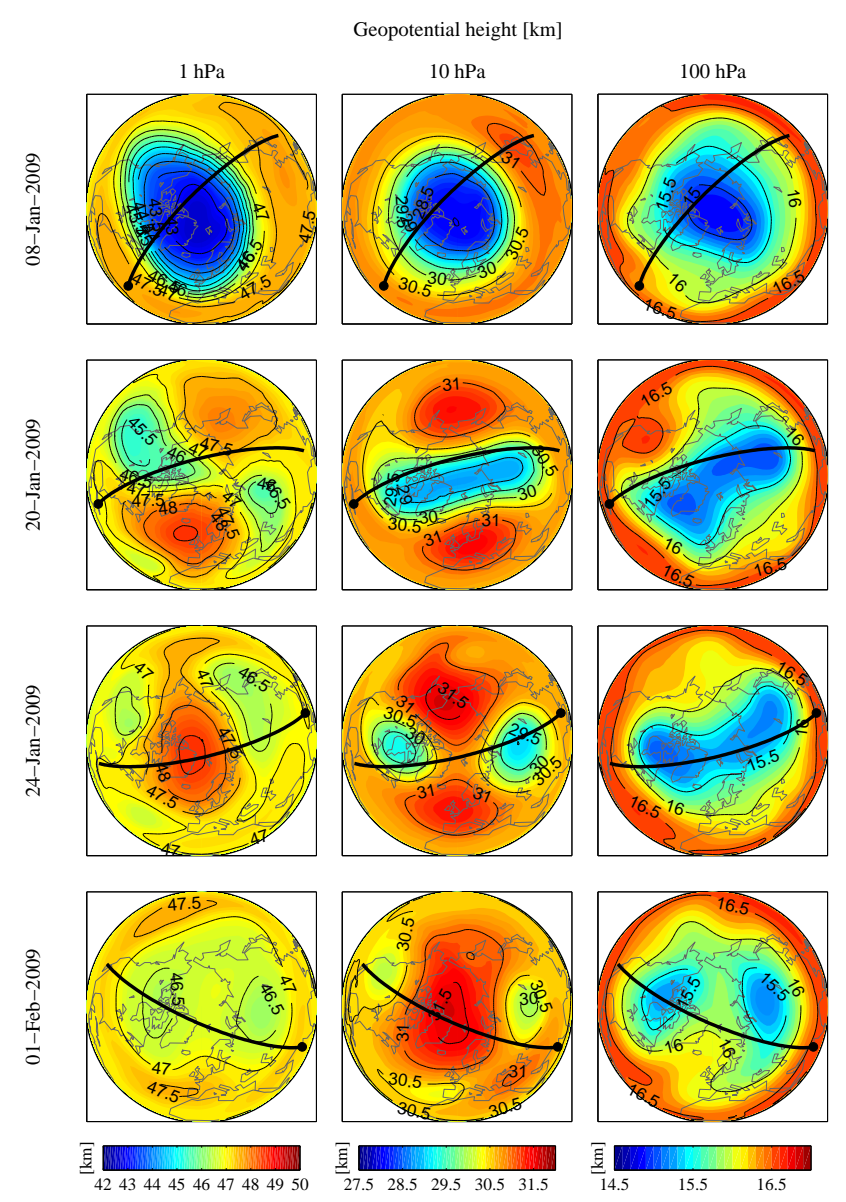

Fig. 2. NH ECMWF geopotential height field (km) at 12:00 UTC on various dates in 2009 (8 January, top row; 20 January, second row; 24 January, third row; 1 February, bottom row) and various pressure levels $(1 \mathrm{hPa}$, left column; $10 \mathrm{hPa}$, middle column; $100 \mathrm{hPa}$, right column). Red indicates relatively high geopotential height values (anticyclonic circulation); blue indicates relatively low geopotential height values (cyclonic circulation). Orbits indicated are used to produce the plots comparing the analyses, measurements and PV in Figs. 4-6. The starting point of each orbit is labelled with a closed circle.

split type. At $10 \mathrm{hPa}$, the anticyclones remain comparable in strength to the cyclonic circulations. At $1 \mathrm{hPa}$, there is a strong anticyclone over the North Pole, and the polar vortex has split into three weak circulations located over East Siberia, North West America and the Atlantic. At this time the polar vortex is severely distorted in the mid and upper stratosphere.

By 1 February (Fig. 2, bottom row), there are two distinct cyclonic circulations at $100 \mathrm{hPa}$, located over North America and Central Siberia, indicating a vortex split (Manney et al., 2009 b, states that the vortex split on $\sim 30$ January at $520 \mathrm{~K}$, $\sim 50 \mathrm{hPa}$ ); the timings of the vortex split in the upper, mid and lower stratosphere ( $\sim 20$ January, $\sim 24$ January and $\sim 30$ January, respectively) are consistent with the typical top-down 
development of major warmings. At $10 \mathrm{hPa}$ the anticyclone is strong and is located over the North Pole; the cyclonic circulations, located over North West America, Central Siberia and South West Europe, have weakened (and are weaker than the anticyclone). At $1 \mathrm{hPa}$ the circulation is dominated by a broad but weak cyclonic system with two circulations, located over Northern Canada and Central Siberia. At high latitudes, there is no longer a signature of an anticyclone at $1 \mathrm{hPa}$. At this time the polar vortex has recovered in the upper stratosphere, but is severely distorted in the lower and mid stratosphere.

The evolution of the stratospheric polar vortex during February is described in Manney et al. (2009b). No significant recovery of the lower stratospheric vortex occurs after the major warming. By mid February, the vortex has strengthened in the upper stratosphere and remains severely distorted in the lower and mid stratosphere. Zonal mean zonal winds remain westerly in the upper mesosphere $(\sim 90 \mathrm{~km})$ until mid March and in the lower mesosphere $(\sim 75 \mathrm{~km})$ until the end of March (see Fig. 1 in Manney et al., 2009b).

\section{Evolution of water vapour analyses and PV fields}

\subsection{Data assimilation versus gridding picture}

We first illustrate the benefit of data assimilation with respect to gridded observations. To do this we compare for 24 January BASCOE water vapour analyses with analogous fields of gridded MLS water vapour observations at $850 \mathrm{~K}$ $(\sim 10 \mathrm{hPa})$ (Fig. 3$)$. The MLS data are linearly interpolated onto the latitude-longitude grid $2^{\circ} \times 5^{\circ}$ as in Manney et al. (2007) - see their Fig. 4. BASCOE analyses are shown for five time-stamps (00:00, 06:00, 12:00, 18:00 and 24:00 UTC), panels 1-5, Fig. 3; gridded MLS data are a 24-h average, panel 6, Fig. 3.

Figure 3 shows that at the time of the major warming both the gridded data and analyses show the same broad-scale features; however, the analyses are more fluid-like than the gridded observational data. In particular, the analyses do not have the signature of the orbits and other noisy features seen in the gridded data. Because gridding of MLS data does not take account of observational error, noisy features in the data are retained in Fig. 3 (panel 6). The spatial relationship between dynamical features (e.g. cyclonic and anticyclonic circulations, identified by relatively high and relatively low water vapour values, respectively) becomes clearer in the analyses. Figure 3 also shows that the BASCOE water vapour analyses capture well the temporal evolution of the water vapour field. Although the above features seen for 24 January (and confirmed for 8 and 20 January, and 1 February - not shown) do not guarantee that the analyses are physically more realistic than the gridded observations, they suggest that the analyses provide a more physically based description of the
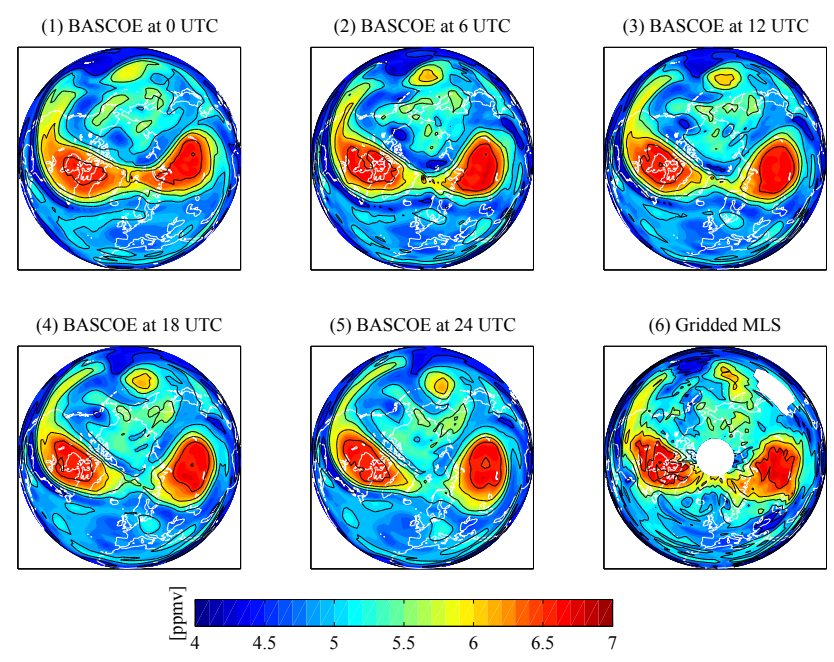

Fig. 3. BASCOE water vapour analyses (ppmv) at 00:00, 06:00, 12:00, 18:00 and 24:00 UTC on 24 January 2009 at 850 K (panels $1-5$, respectively); gridded MLS water vapour observations (ppmv; 24-h average) on 24 January 2009 at $850 \mathrm{~K}$ (panel 6). Red indicates relatively high values; blue indicates relatively low values. White areas in panel 6 indicate a lack of observations.

spatio-temporal evolution of the major warming and, thus, a better basis for quantifying descent in the vortex (as done in Sects. 5.1-5.2).

\subsection{Combined 2-D maps/1-D along-orbit picture}

We now use a combined 2-D maps/1-D along-orbit picture to study the period of the major warming using water vapour analyses and PV fields. In Figs. 4-6 we present for selected dates (8, 20, 24 January; 1 February) and theta levels (550 K, $850 \mathrm{~K}, 1700 \mathrm{~K}$ ), the BASCOE water vapour analyses (left columns) and the ECMWF PV fields (middle columns). The PV fields are shown in PV units, which is appropriate as in each case we focus on one isentropic level. The vortex edge (marked by the bold red contour in the left and middle columns) is defined using the $1.4 \times 10^{-4} \mathrm{~s}^{-1}$ scaled PV (sPV) discussed in Manney et al. (2007) - the location of the vortex edge is superimposed on the water vapour analyses and the PV fields. Right columns show BASCOE analyses and PV fields linearly interpolated to the orbit indicated in the left/middle columns, which marks the location of MLS water vapour observations. Using PV fields derived from GEOS-5 (Manney et al., 2007; http://mls.jpl.nasa.gov/dmp) shows no significant differences in the results (not shown).

Figure 4 concerns the $550 \mathrm{~K}$ level $(\sim 40 \mathrm{hPa}$, lower stratosphere); Fig. 5 the $850 \mathrm{~K}$ level ( $\sim 10 \mathrm{hPa}$, mid stratosphere); and Fig. 6 the $1700 \mathrm{~K}$ level ( $\sim 2 \mathrm{hPa}$, upper stratosphere). The ECMWF PV fields shown in Figs. 4-6 are calculated using ECMWF vorticity and temperature at a horizontal resolution of $1^{\circ} \times 1^{\circ}$, and at 12:00 UTC. PV maps are shown at this resolution, which means they are at a higher resolution 


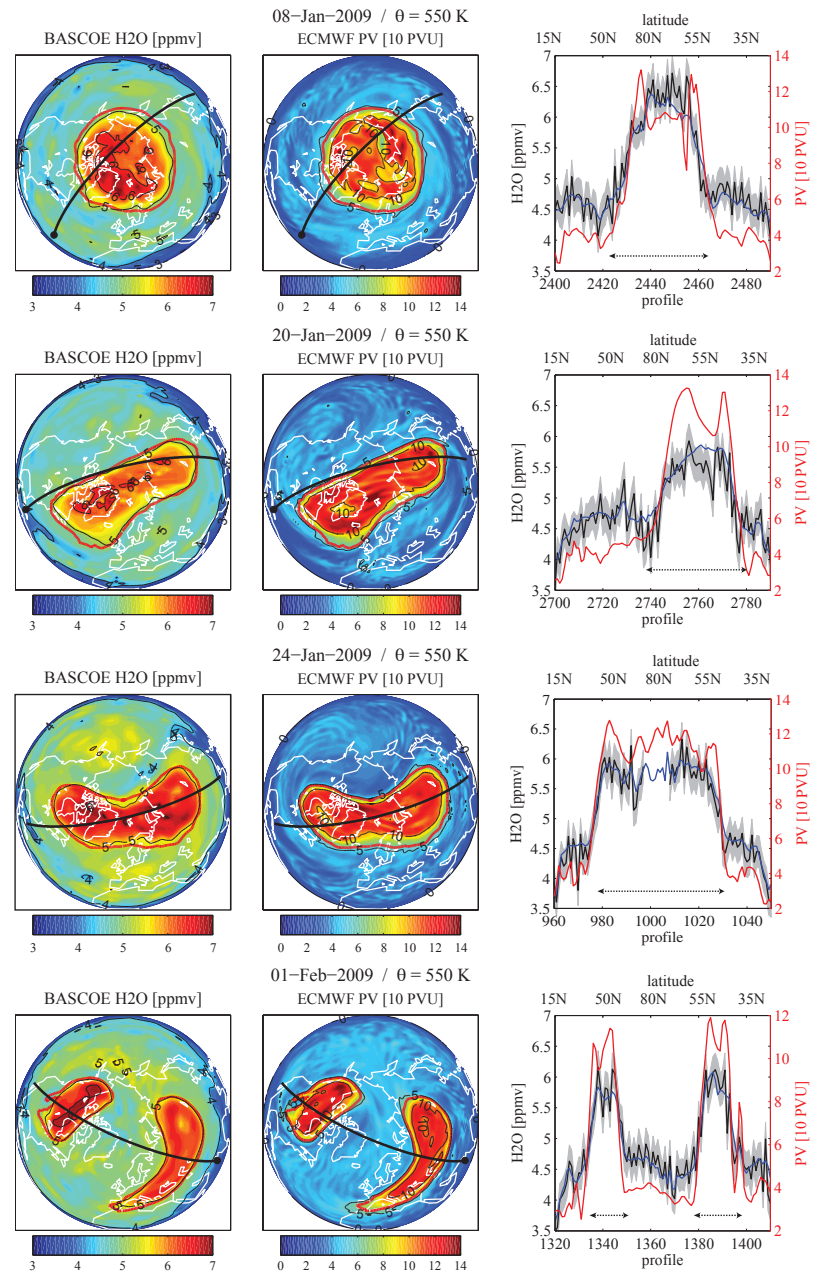

Fig. 4. Plots of geophysical quantities at $550 \mathrm{~K}$. (Left column) NH BASCOE water vapour analyses, ppmv; (Middle column) $\mathrm{NH}$ ECMWF PV field $(10 \times$ PV units); (Right column) MLS water vapour measurements (black line, ppmv; on orbits indicated), and BASCOE water vapour analyses (blue line, ppmv) and ECMWF PV fields (red line, $10 \times$ PV units) interpolated to the orbits indicated in left and middle columns. On right column plot, orbit profile numbers are indicated at the bottom, and approximate latitudes are indicated at the top. Top row: 8 January 2009; second row: 20 January 2009; third row: 24 January 2009; bottom row: 1 February 2009. In left and middle columns, red indicates relatively high values; blue indicates relatively low values; bold red contours indicate the vortex edge (see text for definition). In right column, grey indicates the 1-sigma precision in the MLS water vapour measurements. Dashed horizontal lines in the right column plots indicate regions of relatively high PV identified with the polar vortex.

than the BASCOE analyses. Note that Lahoz et al. (2009) have tested the performance of the ECMWF PV in the upper stratosphere/lower mesosphere (in particular, the performance at the $1900 \mathrm{~K}$ level, $\sim 0.8 \mathrm{hPa}$, was evaluated) and find it provides a realistic description of the large-scale dynamics.
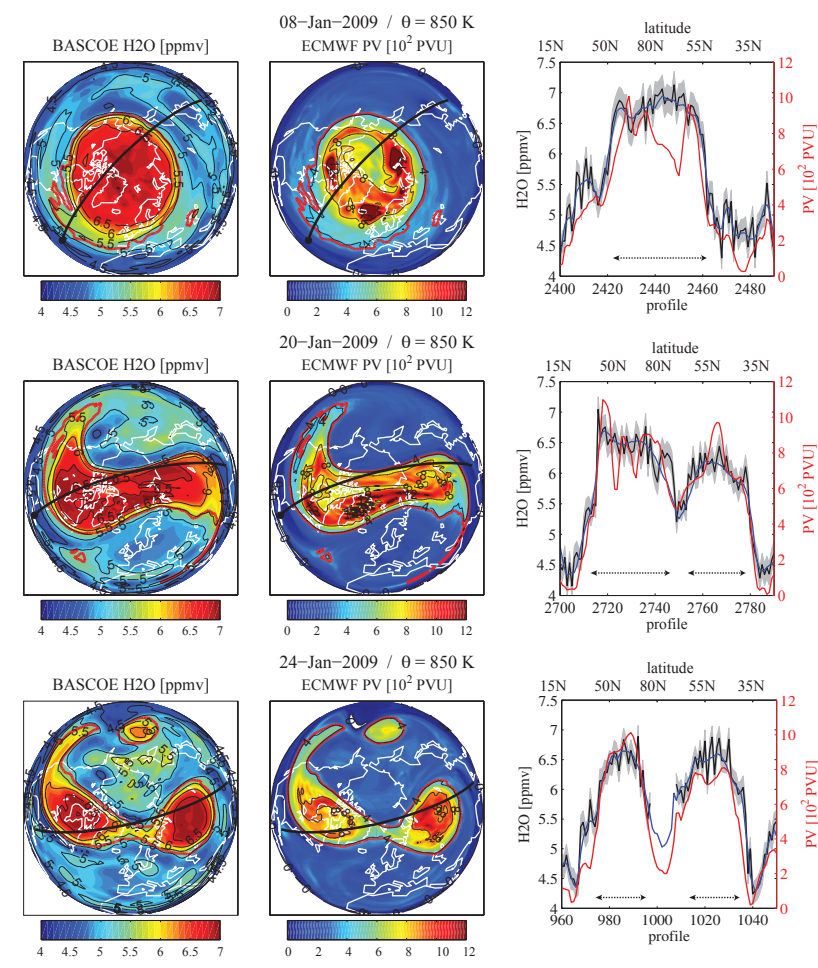

$24-\mathrm{Jan}-2009 / \theta=850 \mathrm{~K}$
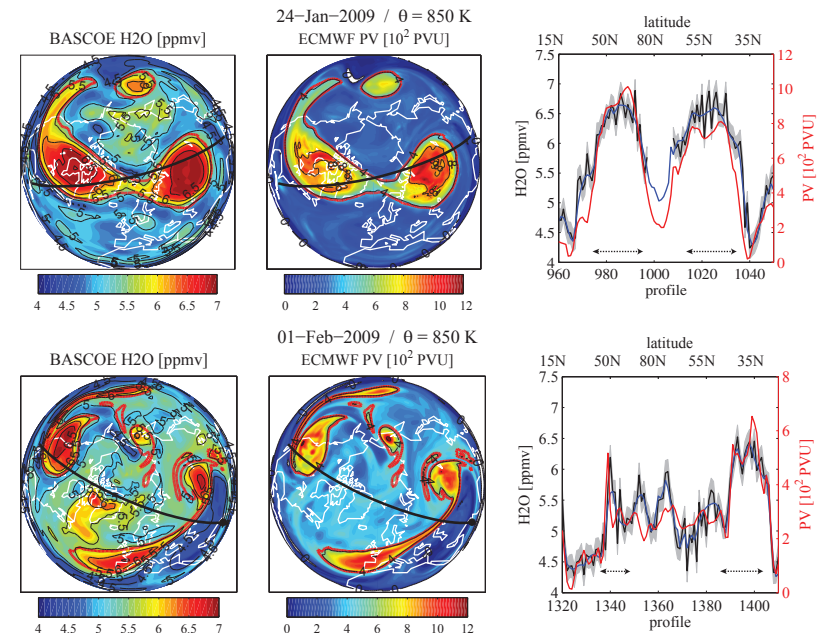

Fig. 5. As Fig. 4 but at $850 \mathrm{~K}$. The PV field is depicted in $10^{2} \times \mathrm{PV}$ units.

Comparison of Figs. 2, 4-5 shows that during the period 8 January-1 February, throughout the lower and mid stratosphere, cyclonic circulations in geopotential height fields are generally reflected in relatively high values in the water vapour analyses and ECMWF PV fields; anticyclonic circulations in the geopotential height fields are reflected in relatively low values in the water vapour analyses and PV fields. By contrast, during January in the upper stratosphere the relationship between geopotential height and water vapour is mainly opposite (Figs. 2, 6). In the period at the end of January and beginning of February, this behaviour in the upper stratosphere is modified. On 1 February both correlation and anti-correlation between $\mathrm{H}_{2} \mathrm{O}$ and $\mathrm{PV}$ fields are seen in the polar vortex at $1700 \mathrm{~K}$ (Fig. 6, bottom row): e.g., anticorrelation just north of Eastern Siberia or over the Canadian Arctic (low $\mathrm{H}_{2} \mathrm{O}$, high PV); correlation over the Bering straits (high $\mathrm{H}_{2} \mathrm{O}$, high PV). This behaviour is explained below. 


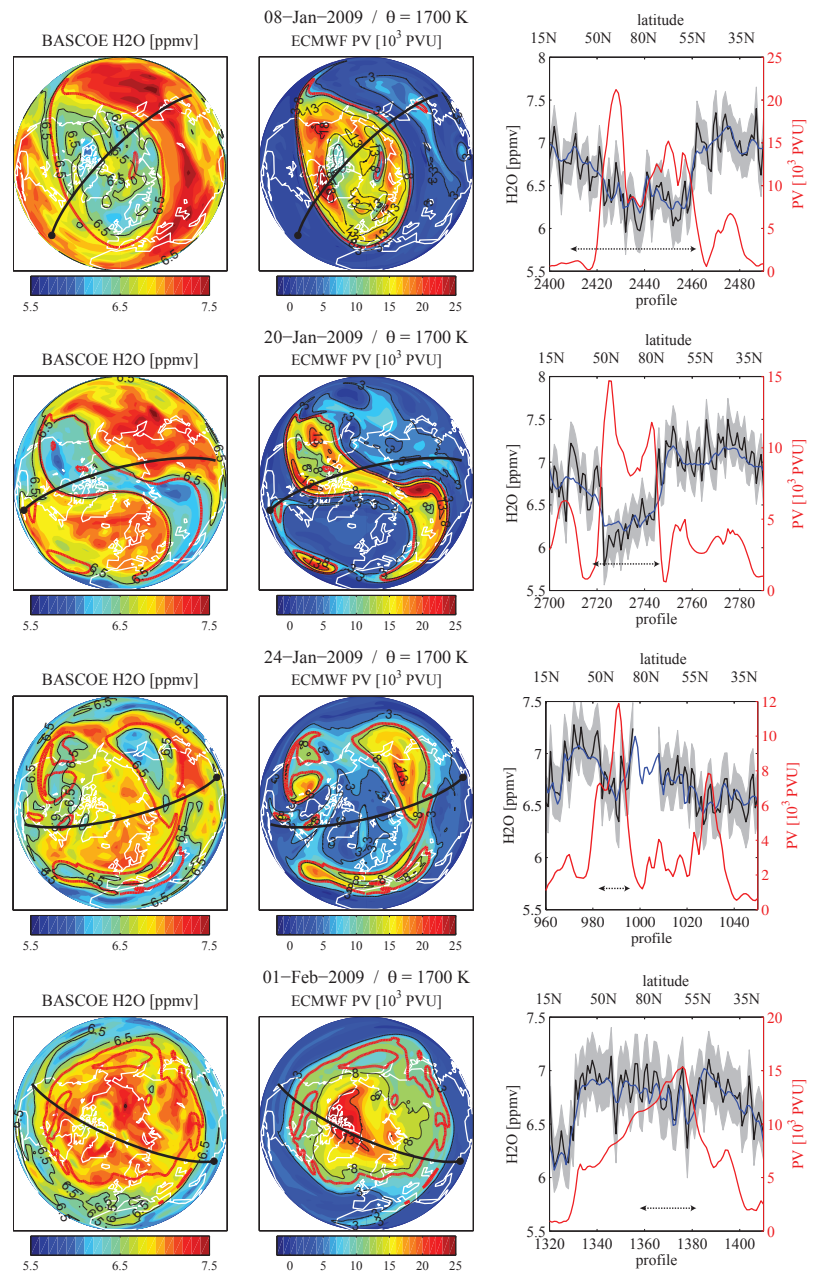

Fig. 6. As Fig. 4 but at $1700 \mathrm{~K}$. The PV field is depicted in $10^{3} \times \mathrm{PV}$ units.

The temporal evolution and spatial distribution of the water vapour analyses and ECMWF PV fields described above is consistent with the strong diabatic descent typical of the Arctic autumn and early winter (e.g., Manney et al., 1994) and shown in other MLS trace gases during the 2005, 2006 and 2009 northern winters by Manney et al. (2007, 2009a, b), with descent during January bringing down relatively dry mesospheric air at high latitudes to the upper and mid stratosphere (where the ambient air is relatively moist), in regions identified by higher PV values, i.e., the polar vortex. By late January after major warming criteria are met on 24 January, the dry mesospheric air has not yet descended to the mid stratosphere. After late January, as the relatively dry air mixes with the ambient moister air, the water vapour mixing ratios throughout the upper and mid stratosphere increase, reflecting the larger extent of the ambient air mass. This has the effect of modifying the relationship at $1700 \mathrm{~K}$ between the relative moistness/dryness of the air masses and the relative magnitude of the PV associated with them: during the first 3-4 weeks of January, $\mathrm{H}_{2} \mathrm{O}$ and PV are anti-correlated; during late January/early February areas of correlation and anti-correlation are present; during mid and late February, $\mathrm{H}_{2} \mathrm{O}$ and $\mathrm{PV}$ are correlated (not shown). Several authors (Feist et al., 2007; Lahoz et al., 2009; Harvey et al., 2009) have commented on modification of PV/tracer correlations.

Comparison of the fields at $550 \mathrm{~K}$ (Fig. 4; other orbit cuts show similar behaviour) shows that, qualitatively, the water vapour analyses and water vapour observations track the PV values, with relatively low values at low and mid $\mathrm{NH}$ latitudes and high values at high $\mathrm{NH}$ latitudes on 8 January, when the polar vortex in the lower stratosphere is not very distorted and is centred roughly over the North Pole. This is confirmed in the agreement between the location of the cyclonic circulation in Fig. 2 (top row), the vortex identified by relatively high PV values in Fig. 4 (top row, middle column), and the along-orbit cuts (Fig. 4, top row, right column). In Figs. 4-6 (right column), the profiles and latitudes with relatively high PV values are marked by dashed horizontal lines.

As the vortex elongates over the period 20-24 January, the water vapour fields continue to track the evolving PV field, with relatively high/low values in the former corresponding to relatively high/low values in the latter. This is confirmed in the agreement between the water vapour and PV analyses, and the along-orbit cuts in Fig. 4: second row and third row, right column. By 1 February, when the vortex has split into two, the split is seen in both the water vapour and the PV field, with relatively high values in both fields corresponding to cyclonic circulations, and relatively low values in both fields corresponding to air in between cyclonic circulations. This is confirmed in the agreement between the water vapour and PV analyses, and the along-orbit cuts in Fig. 4, fourth row, right column.

Inspection of the water vapour and PV along-orbit plots at $850 \mathrm{~K}$ (Fig. 5; other orbit cuts show similar behaviour) shows that, qualitatively, the water vapour analyses and water vapour observations also track the evolving PV field during the period of the major warming. This is confirmed in the agreement between the cyclonic circulations in Fig. 2, and the vortex features identified by relatively high PV values and relatively high water vapour values in Fig. 5, right column. The PV maps on 8 January at $850 \mathrm{~K}$ (and $1700 \mathrm{~K}$; see below) show pockets of relatively low PV inside the vortex, an example that PV and tracers may not both increase monotonically into the polar vortex.

Inspection of the water vapour and PV line plots at $1700 \mathrm{~K}$ (Fig. 6; other orbit cuts show similar behaviour) shows that, qualitatively, the water vapour analyses and water vapour observations also track the evolving PV field during the period of the major warming, but with an opposite relationship between the water vapour data and the PV analyses until the end of January, which can be understood in terms of the confined diabatic descent characteristic of the Arctic vortex in early winter (see discussion above). This is confirmed in the agreement between the cyclonic circulations in Fig. 2, and 
the vortex features identified by relatively high $\mathrm{PV}$ values and relatively low water vapour values for 8, 20 and 24 January in Fig. 6, right column. For 1 February, the PV and water vapour fields are not generally anti-correlated in the regions of highest PV values (Fig. 6, right column, bottom row).

In Figs. 4-6, MLS observations show oscillations within the 1-sigma random error bars (solid grey lines in the right column show the estimated precision of the MLS water vapour observations). Gaps in the MLS data identify particularly poor MLS retrievals (either the retrieval did not converge, or too few radiances are available for a good retrieval - see Livesey et al., 2007). These data were not assimilated. Although MLS observations present a higher variability than the BASCOE analyses, these two datasets agree within the 1-sigma MLS random error bars. The BASCOE analyses and PV fields are smoother than the observations. At the large-scale, all three fields generally agree well, whereas at the small-scale, the BASCOE analyses agree better with the PV fields. The reason the BASCOE water vapour analyses and PV fields are smoother than the water vapour measurements is likely owing to the assimilation that, by its nature, smoothes the observations, and the relatively higher horizontal resolution of the PV fields.

\section{Water vapour analyses: vortex descent during winter 2009}

\subsection{Vortex descent: vortex average picture}

To estimate vortex descent during this winter we first present, for 1 January-28 February 2009, a time series of the vortexaveraged water vapour throughout the stratosphere and lower mesosphere $(400 \mathrm{~K}-2000 \mathrm{~K})$. The time series are computed from analyses (Fig. 7, top), and a BASCOE CTM simulation without assimilation and including chemistry (Fig. 7, middle). The vortex average is computed for PV values identified to be within the polar vortex; the vortex edge is defined using the $1.4 \times 10^{-4} \mathrm{~s}^{-1}$ scaled PV discussed in Manney et al. (2007). The white area in Fig. 7 corresponds to the region where the vortex is not defined according to this criterion. The difference between the BASCOE analyses and the BASCOE CTM simulation is plotted in Fig. 7, bottom. Using PV fields derived from GEOS-5 shows no significant differences in the results (not shown).

A BASCOE CTM simulation without assimilation and without chemistry was also done, with results very similar to those including chemistry (not shown), indicating that advection and not chemistry is the dominant process during the period of the major warming. Comparison of the BASCOE CTM (run without assimilation) against independent data (ACE-FTS) shows that in the stratosphere the model has a positive bias (within $5 \%$ ) and that differences have a standard deviation (about the mean difference) within $10 \%$. In general, the BASCOE CTM (run without assimilation) per-
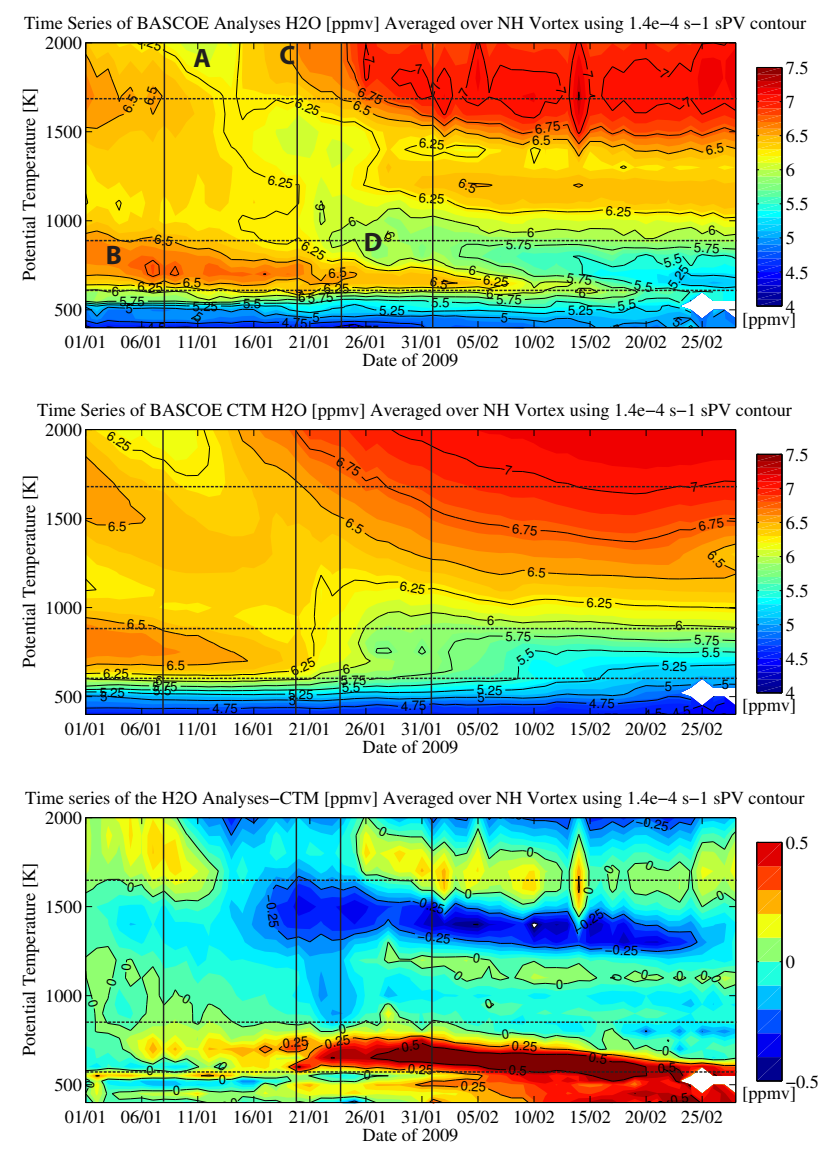

Fig. 7. Times series of NH vortex-averaged water vapour (ppmv) for 1 January-28 February 2009 and theta range $400 \mathrm{~K}-2000 \mathrm{~K}$. (Top) From BASCOE analyses; (Middle) from BASCOE CTM run (no assimilation), with chemistry; (Bottom) difference between top and middle plots. In top and middle plots, blue-green denotes relatively low values; red denotes relatively high values. In bottom plot, red denotes positive differences (analyses values higher than CTM values), blue denotes negative differences (analyses values lower than CTM values). The vortex average is computed for PV values identified to be within the polar vortex. The vortex edge is defined using the $1.4 \times 10^{-4} \mathrm{~s}^{-1}$ scaled PV discussed in Manney et al. (2007). The white area indicates where it is not possible to calculate the vortex edge. The vertical black solid lines identify dates 8, 20 and 24 January, and 1 February (left to right). The horizontal black dashed lines identify theta levels $550 \mathrm{~K}, 850 \mathrm{~K}$ and $1700 \mathrm{~K}$ (bottom to top). A, B, C and D marked in the top plot identify features discussed in the text, and mentioned in Table 1 (for A, B and $\mathrm{C}$ ).

forms worse than the BASCOE analyses (against the ACEFTS data), although differences are small (between $2 \%$ and $5 \%$ ).

Regarding the relative role of advection and chemistry on the water vapour stratosphere/mesosphere distribution, McCormack et al. (2008) have tested the representation and impact of chemistry on water vapour analyses and forecasts. 
They found that a new parametrization accounting for photochemical sources and sinks of water vapour in height, latitude and season, improved global 10-day forecasts of upper mesosphere water vapour in comparison to a simpler 1D parametrization. Most of the improvement was seen at high winter latitudes. We can infer that chemistry is likely to play an important role in the wintertime distribution of water vapour in the mesosphere, and in determining the amount of dry mesospheric air descending into the stratospheric polar vortex. However, results in this paper indicate that during the period of the major warming, advection is the dominant process in determining the water vapour distribution.

The BASCOE water vapour analyses in Fig. 7 (top) show four notable features: (i) an air mass characterized by water vapour mixing ratios of $\sim 6 \mathrm{ppmv}$ (yellow-green colours, marked A), present in the lower mesosphere $(2000 \mathrm{~K})$ during early and mid January, which descends to the mid stratosphere (identified by green patches between $6.25 \mathrm{ppmv}$ contours at $\sim 1500 \mathrm{~K}$ and $\sim 1200 \mathrm{~K}$ - note another green patch can be identified between $\sim 1100 \mathrm{~K}$ and $\sim 1000 \mathrm{~K}$ ) by 24 January (the date major warming criteria were met), with descent appearing to stop abruptly (there is, through most of the vertical range and time period considered, still diabatic descent taking place, but strong mixing as the vortex breaks up destroys the signature of confined descent in the tracer fields) - remnants of this descent continue to be present during late January/early February (e.g. at $\sim 1400 \mathrm{~K}$ ); (ii) an air mass characterized by water vapour mixing ratios greater than 6.5 ppmv (red colours, marked B), present in the mid stratosphere $(\sim 800 \mathrm{~K})$ during early January, which descends to the $\mathrm{mid} /$ lower stratosphere $(\sim 700 \mathrm{~K})$ by 1 February and then stalls; (iii) an air mass characterized by water vapour mixing ratios greater than $6.5 \mathrm{ppmv}$ (red colours, marked C), present in the lower mesosphere $(\sim 1900 \mathrm{~K})$ in 20 January, which descends to the upper stratosphere $(\sim 1500 \mathrm{~K})$ by 15 February, with descent stalled afterwards; and (iv) an air mass characterized by water vapour mixing ratios less than 6 ppmv (green-blue colours, marked D) present in the mid stratosphere during late January, which descends slowly, and becomes drier during February. The origins of features A-C and their relationship to the major warming were discussed in Sect. 4.2.

The origin of the air mass indicated by $\mathrm{D}$ is likely to be mixing at mid stratosphere levels of extra-vortex air (associated with low PV/low water vapour values) with vortex air (associated with high PV/high water vapour values), which would result in drying of the original vortex air. This inference is supported by Fig. 5 (third and fourth row), which generally shows within the polar vortex at $850 \mathrm{~K}$ air masses with correlated PV/water vapour values on 24 January and 1 February, with PV values decreasing between 24 January and 1 February. The observed correlation between PV and water vapour values would discount descent within the polar vortex of relatively dry air from the polar mesosphere, as this air would have an anti-correlation between PV and water vapour values (see Fig. 6 for 8, 20 and 24 January). During the second half of February, as the vortex weakens, further mixing between vortex and extra-vortex air masses slightly decreases water vapour mixing ratios in the lower mid stratosphere (levels $\sim 600 \mathrm{~K}$ ), contributing to the further drying of the air mass indicated by $\mathrm{D}$.

The vortex average calculated from the CTM run (Fig. 7, middle) generally shows the same broad-scale features as the vortex average calculated from the BASCOE analyses (Fig. 7, top), but shows differences in the representation of localized features. The CTM-based estimate shows higher mixing ratios in the mid and upper stratosphere, and lower mixing ratios in the mid and lower stratosphere during the peak of the major warming (20-24 January), and shows higher mixing ratios in the upper stratosphere in the period after the major warming (late January/February). These differences can be as large as $0.5 \mathrm{ppmv}$ in magnitude, as indicated by the difference plot in Fig. 7, bottom. A likely reason for the differences between the analyses and the CTM is that the latter generally has smoother tracer fields because the transport processes in the CTM allow more exchange between air masses (e.g. inside and outside the vortex), than suggested by other fields (geopotential height, PV). This shortcoming in the CTM might be remedied by increasing its spatial resolution (see, e.g., Strahan and Polansky, 2006).

As localized features seen in the BASCOE analyses are consistent with the meteorological data and other tracer data (see Manney et al., 2009b; and Sect. 4, this paper), we infer that vortex-averaged estimates calculated from the BASCOE analyses are more realistic than those calculated from the CTM runs (with and without chemistry). Examples include the relative maximum at $\sim 1400 \mathrm{~K}$ seen during early February in the MLS CO field (Manney et al., 2009b, their Fig. 2, top), replicating the relative maximum seen in the BASCOE water vapour analyses; and consistency between the BASCOE water vapour analyses and the ECMWF PV fields (Figs. 4-6). These results suggest forcing a CTM with ECMWF winds and diabatic heating corresponding to the ERA Interim analyses (and not using data assimilation) produces polar vortex tracer fields (dependent on transport and not chemistry) with biases of at most $0.25-0.5 \mathrm{ppmv}$ - the sign of the bias can be negative or positive depending on altitude. These biases are estimated as the difference between BASCOE analyses and CTM fields without assimilation (see Fig. 7, bottom).

We now estimate vortex descent rates during January and February 2009 using the vortex average picture by considering features marked A-C in Fig. 7 (top). In Sect. 5.2 we estimate vortex descent rates for these features using the equivalent latitude-theta picture and information from Manney et al. (2009b). Section 5.3 summarizes results from Sects. 5.15.2 .

The feature marked A in Fig. 7 (top) is associated with typical early winter diabatic descent in the polar vortex (Manney et al., 1994, 2009a, b). This confined descent brings relatively dry mesospheric air to the mid stratosphere, where the 
ambient air is moister. Figure 2 in Manney et al. (2009b) shows similar strong descent in the MLS CO observations. Focusing on $\mathrm{H}_{2} \mathrm{O}$ mixing ratios less than $6.25 \mathrm{ppmv}$, these isopleths descend (although not in a coherent fashion) from $2000 \mathrm{~K}$ on 8 January to $\sim 1300 \mathrm{~K}$ on 24 January (this level is selected as representative of a range of vertical levels to which air masses with these mixing ratios have descended - see discussion in Sect. 5.1), when they appear to stop abruptly; on this date major warming criteria are met and the vortex splits in the mid stratosphere (Manney et al., 2009b), resulting in strong mixing that eliminates the signature of confined descent. This gives a descent rate of the isopleths of $\sim 40 \mathrm{~K} \mathrm{day}^{-1}$, or $\sim 0.7 \mathrm{~km} \mathrm{day}^{-1}(50 \mathrm{~km}$ to $40 \mathrm{~km}$ in 16 days). An alternative approach focusing on the green colours (isopleths of $\sim 6 \mathrm{ppmv}$ and less) around 12 January, shows descent from $2000 \mathrm{~K}$ (12 January) to $\sim 1500 \mathrm{~K}$ (25 January), a descent rate of $\sim 40 \mathrm{~K} \mathrm{day}^{-1}$. This suggests descent rates for this air mass of $\sim 40 \mathrm{Kday}^{-1}$. Here and elsewhere in the paper, descent rates in units of $\mathrm{Kday}^{-1}$ are in terms of $d$ (theta)/dt.

The feature marked B in Fig. 7 (top) is associated with descent before the major warming (24 January) and the subsequent vortex split in the mid and mid/lower stratosphere (Manney et al., 2009b). This air does not mix with the relatively drier air of mesospheric origin immediately above. This descent of air brings relatively moist mid/upper stratospheric air to the mid stratosphere, where the ambient air is drier. Figure 2 in Manney et al. (2009b) shows similar descent in the MLS $\mathrm{N}_{2} \mathrm{O}$ observations. Focusing on $\mathrm{H}_{2} \mathrm{O}$ mixing ratios of $6.5 \mathrm{ppmv}$, these isopleths descend from $\sim 1000 \mathrm{~K}$ in 1 January to $\sim 800 \mathrm{~K}$ by 9 February; after this time the isopleths stall and stop descending. This implies a descent rate of $\sim 5 \mathrm{~K} \mathrm{day}^{-1}$ for this air mass. An alternative approach focusing on the red colours between $6.5 \mathrm{ppmv}$ and 6.75 ppmv shows descent from $850 \mathrm{~K}$ ( 1 January) to $\sim 750 \mathrm{~K}$ (22 January), also a descent rate of $\sim 5 \mathrm{~K} \mathrm{day}^{-1}(\sim 30 \mathrm{~km}$ to $\sim 20 \mathrm{~km}$ over 20 days, a descent rate of $\sim 0.5 \mathrm{~km} \mathrm{day}^{-1}$ ). During this descent, and especially after the peak of the warming in 24 January, the region of locally high mixing ratios (e.g. values greater than $6.5 \mathrm{ppmv}$ ) decreases, suggesting mixing between extra-vortex and vortex air as the vortex splits.

The feature marked C in Fig. 7 (top) is associated with strong descent after the major warming (24 January) and subsequent reformation of the vortex in the upper stratosphere/mesosphere (Manney et al., 2009b). This descent of air brings relatively moist upper stratosphere/mesosphere air to the mid stratosphere, where the ambient air is drier. Note that mixing between relatively dry vortex air and relatively moist extra-vortex air at $\sim 1700 \mathrm{~K}$ during the warming contributes to the increase in mixing ratios seen after 24 January; analogous mixing between vortex and extra-vortex air contributes to the slight increase in mixing ratios seen from 21 January to 31 January between $\sim 1500 \mathrm{~K}$ and $\sim 1100 \mathrm{~K}$. Figure 2 in Manney et al. (2009b) shows similar strong de- scent in the MLS CO observations. Focusing on $\mathrm{H}_{2} \mathrm{O}$ mixing ratios of $6.5 \mathrm{ppmv}$, these isopleths descend from $2000 \mathrm{~K}$ on 20 January to $\sim 1500 \mathrm{~K}$ on 10 February; after this time the isopleths stop descending. This implies a descent rate of $\sim 25 \mathrm{~K} \mathrm{day}^{-1}(\sim 50 \mathrm{~km}$ to $\sim 40 \mathrm{~km}$ over 20 days, a descent rate of $\sim 0.5 \mathrm{~km} \mathrm{day}^{-1}$ ) for this air mass. An alternative approach focusing on isopleths greater than $6.75 \mathrm{ppmv}$ (red colours) shows descent from $\sim 1900 \mathrm{~K}$ (25 January) to $\sim 1500 \mathrm{~K}$ (14 February), a descent rate of $\sim 20 \mathrm{~K} \mathrm{day}^{-1}$. This suggests descent rates for this air mass between $20 \mathrm{~K}_{\text {day }}{ }^{-1}$ and $25 \mathrm{Kday}^{-1}$.

\subsection{Vortex descent: equivalent latitude-theta picture}

To estimate vortex descent during this winter, we now use the equivalent latitude-theta picture to look at the water vapour fields for the following dates: 8, 20, 24 January; 1 February (respectively, left, middle left, middle right and right columns, Fig. 8). We first compare the BASCOE water vapour analyses (top row, Fig. 8) with two BASCOE CTM free runs (i.e., without data assimilation): one includes chemistry (middle row, Fig. 8); the other excludes chemistry (bottom row, Fig. 8). We then estimate vortex descent rates from the BASCOE analysis information.

The CTM runs show little difference between including or excluding chemistry (middle and bottom row, respectively; Fig. 8), confirming that advection and not chemistry is the dominant process affecting the water vapour distribution during the period of the stratospheric major warming (see discussion in Sect. 5.1). The CTM runs capture the large-scale features of the BASCOE analyses (e.g. general location of maxima/minima in the water vapour distribution), but are unable to capture localized features in the analyses, e.g., the relatively moist air in the mid stratosphere $(\sim 850 \mathrm{~K})$ seen on 24 January and 1 February, and the pockets of relatively dry air seen at $\sim 1500 \mathrm{~K}$ on 20 and 24 January poleward of $60^{\circ} \mathrm{N}$. As localized features seen in the equivalent latitude-theta representation of the BASCOE analyses are consistent with the meteorological data (see Figs. 2, 5 and 6; and Manney et al., 2009b), this illustrates the benefit from data assimilation with respect to the BASCOE CTM. Evidence for the benefit of data assimilation with respect to observations was presented in Sect. 4.1.

The equivalent latitude-theta maps for the BASCOE analyses show several notable features. First, they show relatively dry air (mixing ratios less than 6 ppmv; marked A, top row, Fig. 8) in the mesosphere (theta values greater than $\sim 2100 \mathrm{~K}$ ) poleward of $50^{\circ} \mathrm{N}$ on 8 January, identified to be mainly within the polar vortex in terms of geopotential height (Fig. 2), or of water vapour or PV (Fig. 6). By 20 January, this air mass has descended to $\sim 1500 \mathrm{~K}$ and by 24 January to $\sim 1300 \mathrm{~K}$, mainly remaining within the polar vortex (left column, second and third row; Fig. 2). By 1 February, no mixing ratios lower than 6 ppmv can be seen poleward of $50^{\circ} \mathrm{N}$ and theta levels higher than $\sim 1200 \mathrm{~K}$, suggesting these 


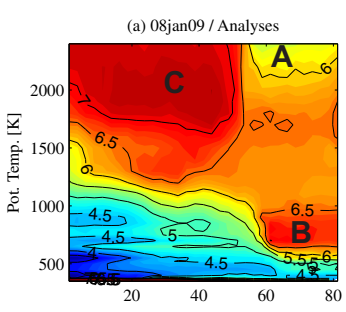

(e) 08 jan 09 / CTM Chem On

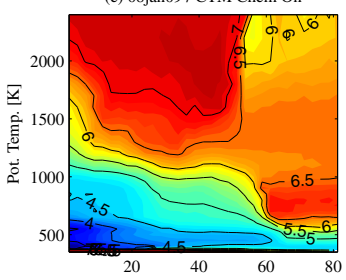

(i) $08 \mathrm{jan} 09 / \mathrm{CTM}$ Chem Off

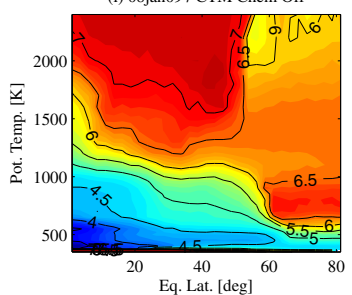

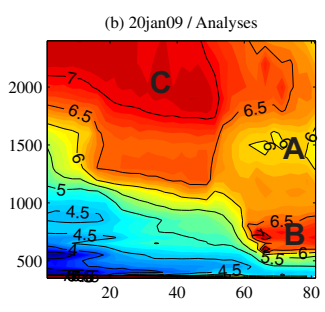

(f) 20jan09 / CTM Chem On

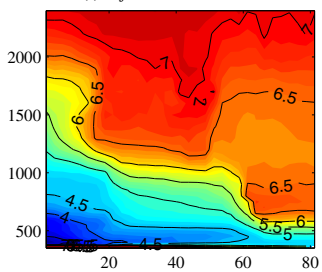

(j) $20 \mathrm{jan} 09$ / CTM Chem Of

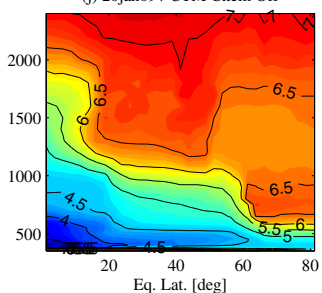

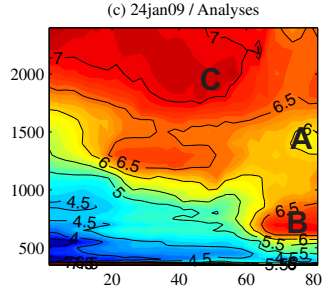

(g) 24jan09 / CTM Chem On

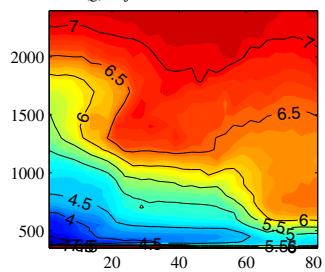

(k) $24 \mathrm{jan} 09 / \mathrm{CTM}$ Chem O

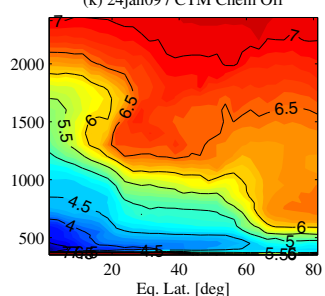

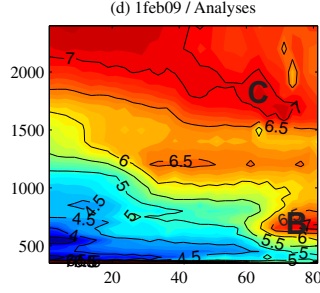

(h) 1 feb09/ CTM Chem On

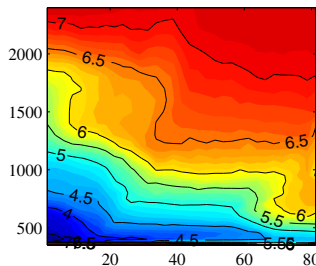

(1) 1 feb09/ CTM Chem Of

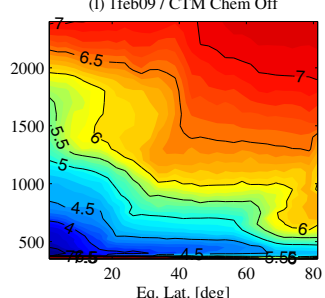

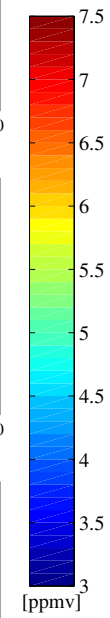

$[\mathrm{ppmv}]$

Fig. 8. Equivalent latitude-theta plots of water vapour fields at 12:00 UTC (ppmv). Top row: BASCOE analyses; middle row: BASCOE CTM run (no assimilation), with chemistry; bottom row: BASCOE CTM run (no assimilation), no chemistry. Left column: 8 January 2009 ; middle left column: 20 January 2009; middle right column: 24 January 2009; right column: 1 February 2009. Red indicates relatively high values; blue indicates relatively low values. A, B and C in the top row plots identify features discussed in the text, and mentioned in Table 1.

air masses of mesospheric origin have mixed in with the relatively moist ambient air at these levels (see discussion in Sect. 4.2). This is consistent with the relatively weak latitudinal gradients in the polar vortex on 1 February at $1 \mathrm{hPa}$ (left column, bottom row; Fig. 2). These results suggest a descent of $\sim 600 \mathrm{~K}$ between 8 January and 20 January (descent rate of $\sim 50 \mathrm{~K} \mathrm{day}^{-1}$ ), and a descent of $\sim 200 \mathrm{~K}$ between $20 \mathrm{Jan}-$ uary and 24 January (descent rate of $\sim 50 \mathrm{~K} \mathrm{day}^{-1}$ also). In Sect. 5.1 we estimated descent rates for this relatively dry air of $\sim 40 \mathrm{~K} \mathrm{day}^{-1}$.

Second, the equivalent latitude-theta maps show an air mass of relatively moist air (mixing ratios greater than 6.5 ppmv; marked B, top row, Fig. 8) in the mid stratosphere $(\sim 600 \mathrm{~K}-\sim 1000 \mathrm{~K})$ poleward of $60^{\circ} \mathrm{N}$ on 8 January, identified to be within the polar vortex in terms of geopotential height (Fig. 2), or of water vapour or PV (Fig. 5). This air mass remains coherent over the rest of January, although decreasing in extent both in the vertical and the horizontal, with its upper layers descending to $\sim 850 \mathrm{~K}$ by 20 January (descent rate of $\sim 10 \mathrm{~K} \mathrm{day}^{-1}$ ) and to $\sim 750 \mathrm{~K}$ by 1 February (descent rate of $10 \mathrm{~K} \mathrm{day}^{-1}$ also). The lower layers of this air mass remain at $\sim 650 \mathrm{~K}$ during this period (8 January-1 February). In Sect. 5.1 we estimated descent rates for this relatively moist air of $\sim 5 \mathrm{~K} \mathrm{day}^{-1}$.
Third, the equivalent latitude-theta maps show poleward transport of relatively moist air (mixing ratios greater than 6.5 ppmv; marked C, top row, Fig. 8) at theta levels higher than $\sim 1300 \mathrm{~K}$ between 8 January and 1 February. At $\sim 1300$ $\mathrm{K}$, the region of relatively moist air (located equatorward of $50^{\circ} \mathrm{N}$ on 8 January) decreases in size during this period, and by 1 February only remnants exist. The part of this air mass located at $\sim 1700 \mathrm{~K}$ descends from $\sim 1700 \mathrm{~K}$ (24 January) to $\sim 1600 \mathrm{~K}$ (1 February), a descent rate of $\sim 10 \mathrm{~K} \mathrm{day}^{-1}$.

We now compare descent rates estimated in this paper with estimates based on Fig. 2 of Manney et al. (2009b), where we consider the motion of tracer isopleths of $\mathrm{CO}$ and $\mathrm{N}_{2} \mathrm{O}$; Manney et al. (2009b) use an equivalent latitude-theta picture to study the wintertime evolution of the polar vortex during January-February 2009. Note that a comparison which considers the motion of tracer isopleths of different tracers (as done here) is likely to incur errors due to different strengths in the horizontal gradients of the tracers. In particular, since $\mathrm{N}_{2} \mathrm{O}$ and $\mathrm{CO}$ have stronger horizontal gradients in the stratosphere/lower mesosphere than water vapour, horizontal mixing would tend to modify these fields more significantly and mask the extent of the vertical descent within the vortex more than for water vapour. This would result in larger descent rates estimated using water vapour than those estimated from Manney et al. (2009b). 
Table 1. Summary of vortex descent rates computed using various approaches. Descent rates are in terms of $d$ (theta)/dt (unless indicated as $\mathrm{km} \mathrm{day}^{-1}$ ).

\begin{tabular}{|c|c|c|c|}
\hline Wintertime feature & $\begin{array}{l}\text { Approach 1: Vortex averaged } \\
\text { picture (Sect. 5.1, Fig. } 7 \\
\text { this paper); } \mathrm{H}_{2} \mathrm{O} \text { analyses }\end{array}$ & $\begin{array}{l}\text { Approach 2: Equivalent latitude- } \\
\text { theta picture (Sect 5.2, Fig. } 8 \text {, } \\
\text { this paper); } \mathrm{H}_{2} \mathrm{O} \text { analyses }\end{array}$ & $\begin{array}{l}\text { Approach 3: Equivalent latitude- } \\
\text { theta picture (Fig. 2, Manney et al. } \\
\text {, 2009b); } \mathrm{CO} \text { and } \mathrm{N}_{2} \mathrm{O} \text { MLS data }\end{array}$ \\
\hline $\begin{array}{l}\text { Early winter diabatic descent } \\
\text { from the mesosphere (marked A, Fig. } 7 \text {, } \\
\text { top; Fig. 8, top row) } \sim 8-\sim 24 \text { January }\end{array}$ & $\begin{array}{l}\sim 40 \mathrm{~K} \mathrm{day}^{-1} \\
\left(\sim 0.7 \mathrm{~km} \mathrm{day}^{-1}\right)\end{array}$ & $\sim 50 \mathrm{~K} \mathrm{day}^{-1}$ & $\sim 30 \mathrm{~K} \mathrm{day}^{-1}$ \\
\hline $\begin{array}{l}\text { Descent before the major warming } \\
\text { (marked B, Fig. 7, top; Fig. 8, top row) } \\
\sim 1-\sim 22 \text { January }\end{array}$ & $\begin{array}{l}\sim 5 \mathrm{~K} \mathrm{day}^{-1} \\
\left(\sim 0.5 \mathrm{~km} \mathrm{day}^{-1}\right)\end{array}$ & $\sim 10 \mathrm{Kday}^{-1}$ & $\sim 3 \mathrm{Kday}^{-1}$ \\
\hline $\begin{array}{l}\text { Strong descent after the major warming } \\
\text { (marked C, Fig. } 7 \text {, top; Fig. } 8 \text {, top row) } \\
\sim 20 \text { January } \sim 15 \text { February }\end{array}$ & $\begin{array}{l}20 \mathrm{~K} \mathrm{day}^{-1}-25 \mathrm{Kday}^{-1} \\
\left(\sim 0.5 \mathrm{~km} . \mathrm{day}^{-1}\right)\end{array}$ & $\begin{array}{l}\sim 10 \mathrm{~K}_{\text {day }}{ }^{-1} \\
\text { (this is estimated for the period } \\
\sim 24 \text { January } \sim 1 \text { February) }\end{array}$ & $\sim 20 \mathrm{~K} \mathrm{day}^{-1}$ \\
\hline
\end{tabular}

From Fig. 2 of Manney et al. (2009b) we estimate the following descent rates: (i) $700 \mathrm{ppbv}$ (parts per billion by volume) CO isopleth from $\sim 2000 \mathrm{~K}$ ( 8 January) to $\sim 1500 \mathrm{~K}$ ( 24 January), a descent rate of $\sim 30 \mathrm{Kday}^{-1}$ (compare with the estimate of $\sim 40 \mathrm{~K} \mathrm{day}^{-1}$ from the vortex averaged quantity); (ii) $40 \mathrm{ppbv} \mathrm{N}_{2} \mathrm{O}$ isopleth from $\sim 700 \mathrm{~K}$ (early January) to $\sim 600 \mathrm{~K}$ (late January), a descent rate of $\sim 3 \mathrm{~K} \mathrm{day}^{-1}$ (compare with the estimate of $\sim 5 \mathrm{~K} \mathrm{day}^{-1}$ from the vortex averaged quantity); and (iii) $350 \mathrm{ppbv} \mathrm{CO}$ isopleth from $\sim 2200 \mathrm{~K}$ (late January) to $\sim 2000 \mathrm{~K}$ (mid February), a descent rate of $\sim 20 \mathrm{~K} \mathrm{day}^{-1}$ (compare with the estimate of $\sim 20 \mathrm{~K} \mathrm{day}^{-1}$ to $\sim 25 \mathrm{~K} \mathrm{day}^{-1}$ from the vortex averaged quantity). The results from the vortex-averaged quantities in Fig. 7 (top) and equivalent latitude-theta picture in Fig. 8 (top row) agree qualitatively with those from Manney et al. (2009b) in the nature and timing of the descent, but tend to overestimate the descent rate based on Manney et al. (2009b). This is to be expected given the different characteristics of the horizontal gradients of $\mathrm{CO}, \mathrm{N}_{2} \mathrm{O}$ and water vapour.

\subsection{Summary of vortex descent}

Descent rates in the vortex of various air masses during the major warming are estimated from BASCOE analyses using a vortex-averaged approach (Sect. 5.1), and an equivalent latitude-theta approach (Sect. 5.2); they are shown to be consistent with each other. These estimates are compared with estimates based on Fig. 2 in Manney et al. (2009b) (Sect. 5.2). Estimates using BASCOE analyses are consistent with those based on Manney et al. (2009b), once consideration is taken of the fact that different tracers are being used, and that these tracers have different horizontal gradients; this suggests BASCOE water vapour analyses are a reasonably good basis for estimating vortex descent rates. Table 1 summarizes these results.

Note that the result for the equivalent latitude approach using the BASCOE water analyses for region marked $\mathrm{C}$ in
Fig. 7 (third column, bottom row of Table 1) shows (at first glance) a lower descent rate than estimated from Manney et al. (2009b). However, the reader should note that the time period used for the estimate in the third column, bottom row of Table 1 is different than that for the vortex average approach for region C (second column, bottom row of Table 1), and than that for the estimate from Manney et al. (2009b) data for region $\mathrm{C}$ (fourth column, bottom row of Table 1). This is noted in Table 1.

The descent rates presented in Table 1 assume diabatic descent of tracer isopleths and exclude quasi-horizontal mixing (see discussion in Sect. 5.1). Estimating the contribution of the latter is outside the scope of this paper. Therefore, the values of $\sim 0.5 \mathrm{~km} \mathrm{day}^{-1} \_\sim 0.7 \mathrm{~km} \mathrm{day}^{-1}$ should be regarded as first-order estimates.

Descent rates in the wintertime mesosphere and upper stratosphere have been estimated by many authors using a number of methods (Lee et al., 2011, and references therein). Lee et al. themselves estimate a descent rate for northern winters 2006 and 2009 (winters with major warmings) of $\sim 0.5 \mathrm{~km} \mathrm{day}^{-1}$ at $60 \mathrm{~km}$, lower than the value of $\sim 0.7 \mathrm{~km} \mathrm{day}^{-1}$ we estimate for the region between $50 \mathrm{~km}$ and $40 \mathrm{~km}$ (Table 1). Note, however, that as Lee et al. discuss, caution must be used in interpreting their results, as chemical and/or dynamical processes not directly related to descent may affect the method they use to estimate descent rates (namely, changes in the maximum of the $\mathrm{CO}$ northern and southern annular mode indices).

\section{Conclusions}

We study the evolution of the record-breaking major stratospheric warming of northern winter 2009 (JanuaryFebruary) from synergistic use of MLS water vapour measurements and BASCOE water vapour analyses. These data are supplemented with meteorological data from ECMWF, 
and PV derived from ECMWF meteorological data. We use a 2-D picture (latitude-longitude maps, equivalent latitudetheta maps) to represent the water vapour analyses and PV fields, and a 1-D along-orbit picture to represent the water vapour analyses, PV fields and MLS water vapour measurements. By combining these pictures we obtain a comprehensive, consistent and physically realistic 3-D picture of the stratosphere during the period of the major warming. This focuses on the interaction between the cyclonic wintertime stratospheric polar vortex and subsidiary anticyclonic stratospheric circulations prevalent during this period.

This study provides evidence of the benefit of using stratospheric water vapour analyses (produced using data assimilation), together with water vapour observations, meteorological data and PV fields, to help understand the 3-D dynamical evolution of the stratosphere during an interesting dynamical event such as a major stratospheric warming. It is shown assimilation of stratospheric water vapour produces more fluid-like fields than gridded observations, and captures the spatio-temporal evolution of the stratosphere during the major warming more realistically than the BASCOE CTM. Data assimilation fills in the observational gaps objectively, and allows estimation of vortex-averaged quantities to provide a realistic picture of descent of tracer isopleths in the stratosphere. First-order estimates of descent rates in the polar vortex $\left(\sim 0.5 \mathrm{~km} \mathrm{day}^{-1} \_\sim 0.7 \mathrm{~km} \mathrm{day}^{-1}\right)$ are realistic and consistent with those estimated from Manney et al. (2009b).

Future work will aim to test further the benefits of the approach used in this paper by applying it to study other interesting stratospheric dynamical and events, including the final warming in the northern and southern winter stratosphere.

Acknowledgements. Thanks to the MLS team and the EOS Aura project for their roles in producing, documenting and distributing the MLS data. Thanks to William Daffer (Jet Propulsion Laboratory) for data analysis/graphics assistance. The WAVACS COST Action funded a Short Term Scientific Mission (STSM) for S. Viscardy to visit NILU. WAL is supported by an internal NILU project and by RTRA/STAE during his time at CNRM-GAME. QE and SV are supported by the Belgian Federal Science Policy in the framework of the SECPEA ProDEx project. Work at the Jet Propulsion Laboratory, California Institute of Technology was done under contract with the National Aeronautics and Space Administration. Thanks to Finn Bjørklid (NILU) for improving various figures. Thanks to Alan Geer and an anonymous reviewer for comments that helped improve the paper.

Edited by: W. Ward

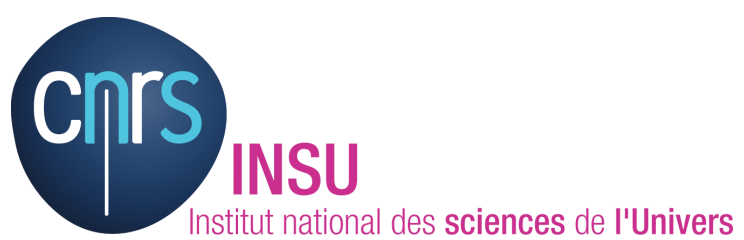

The publication of this article is financed by CNRS-INSU.

\section{References}

Baldwin, M. P. and Dunkerton, T. J.: Stratospheric harbingers of anomalous weather regimes, Science, 294, 581-584, 2001.

Bernath, P. F., McElroy, C. T., Abrams, M. C., Boone, C. D., Butler, M., Camy-Peyret, C., Carleer, M., Clerbaux, C., Coheur, P.-F., Colin, R., DeCola, P., DeMazière, M., Drummond, J. R., Dufour, D., Evans, W. P. J., Fast, H., Fussen, D., Gilbert, K., Jennings, D. E., Llewellyn, E. J., Lowe, R. P., Mahieu, E., McConnell, J. C., McHugh, M., McLeod, S. D., Michaud, R., Midwinter, C., Nassar, R., Nichitiu, F., Nowlan, C., Rinsland, C. P., Rochon, Y. J., Rowlands, N., Semeniuk, K., Simon, P., Skelton, R., Sloan, J. J., Soucy, M.-A., Strong, K., Tremblay, P., Turnbull, D., Walker, K. A., Walkty, I., Wardle, D. A., Wehrle, V., Zander, R., and Zou, J.: Atmospheric Chemistry Experiment (ACE): Mission overview, Geophys. Res. Lett., 32, L15S01, doi:10.1029/2005GL022386, 2005.

Charlton, A. J. and Polvani, L. M.: A New Look at Stratospheric Sudden Warmings. Part I: Climatology and Modeling Benchmarks, J. Climate, 20, 449-469, doi:10.1175/JCLI3996.1, 2007.

Charlton-Perez, A. J., Polvani, L. M., Austin, J., and Li, F.: The frequency and dynamics of stratospheric sudden warmings in the 21st century, J. Geophys. Res., 113, D16116, doi:10.1029/2007JD009571, 2008.

Dethof, A. and Hólm, E.: Ozone assimilation in the ERA-40 reanalysis project, Q. J. Roy. Meteor. Soc., 130, 2851-2872, 2004.

Eckermann, S. D., Hoppel, K. W., Coy, L., McCormack, J. P., Siskind, D. E., Nielsen, K., Kochenash, A., Stevens, M. H., Englert, C. R., Singer, W., and Hervig, M.: High-altitude data assimilation experiments for the northern summer mesosphere season of 2007, J. Atmos. Solar-Terr. Phys., 7, 531-551, 2009.

El Amraoui, L., Semane, N., Peuch, V.-H., and Santee, M. L.: Investigation of dynamical processes in the polar stratospheric vortex during the unusually cold winter 2004/2005, Geophys. Res., Lett., 35, L03803, doi:10.1029/2007GL031251, 2008.

Errera, Q. and Fonteyn, D.: Four-dimensional variational chemical data assimilation of CRISTA stratospheric measurements, J Geophys. Res., 106, 12253-12265, 2001.

Errera, Q., Daerden, F., Chabrillat, S., Lambert, J. C., Lahoz, W. A., Viscardy, S., Bonjean, S., and Fonteyn, D.: 4D-Var assimilation of MIPAS chemical observations: ozone and nitrogen dioxide analyses, Atmos. Chem. Phys., 8, 6169-6187, doi:10.5194/acp8-6169-2008, 2008.

Feist, D. G., Geer, A. J., Müller, S., and Kämpfer, N.: Middle atmosphere water vapour and dynamical features in aircraft measurements and ECMWF analyses, Atmos. Chem. Phys., 7, 52915307, doi:10.5194/acp-7-5291-2007, 2007.

Fisher, M. and Lary, D. J.: Lagrangian 4-Dimensional variational data assimilation of chemical species, Q. J. Roy. Meteor. Soc., 121, 1681-1704, 1995.

Geer, A. J., Lahoz, W. A., Bekki, S., Bormann, N., Errera, Q., Eskes, H. J., Fonteyn, D., Jackson, D. R., Juckes, M. N., Massart, S., Peuch, V.-H., Rharmili, S., and Segers, A.: The ASSET intercomparison of ozone analyses: method and first results, Atmos. Chem. Phys., 6, 5445-5474, doi:10.5194/acp-6-5445-2006, 2006.

Geer, A. J., Lahoz, W. A., Jackson, D. R., Cariolle, D., and McCormack, J. P.: Evaluation of linear ozone photochemistry parametrizations in a stratosphere-troposphere data assimilation system, Atmos. Chem. Phys., 7, 939-959, doi:10.5194/acp-7- 
939-2007, 2007.

Harvey, V. L., Pierce, R. B., Fairlie, T. D., and Hitchman, M. H.: A climatology of stratospheric polar vortices and anticyclones, J. Geophys. Res., 107, 4442, doi:10.1029/2001JD001471, 2002.

Harvey, V. L., Pierce, R. B., Hitchman, M. H., Randall, C. E., and Fairlie, T. D.: On the distribution of ozone in stratospheric anticyclones, J. Geophys. Res., 109, D24308, doi:10.1029/2004JD004992, 2004.

Harvey, V. L., Randall, C. E., and Hitchman, M. H.: Breakdown of potential vorticity-based equivalent latitude as vortex-centered coordinate in the polar winter mesosphere, J. Geophys. Res., 114, D22105, doi:10.1029/2009JD012681, 2009.

Jackson, D. R.: Assimilation of EOS MLS ozone observations in the Met Office Data Assimilation System, Q. J. Roy. Meteor.Soc., 133, 1771-1788, 2007.

Jackson, D. R. and Orsolini, Y. J.: Estimation of Arctic ozone loss in winter 2004/2005 based on assimilation of EOS MLS and SBUV/2 observations, Q. J. Roy. Meteor. Soc., 134, 1833-1841, 2008.

Juckes, M. N.: An annual cycle of long lived stratospheric gases from MIPAS, Atmos. Chem. Phys., 7, 1879-1897, doi:10.5194/acp-7-1879-2007, 2007.

Kalnay, E.: Atmospheric Modeling, Data Assimilation and Predictability, Cambridge University Press, Cambridge, UK, 341 pp., 2003.

Khattatov, B. V., Lamarque, J.-F., Lyjak, L. V., Ménard, R., Levelt, P., Tie, X., Brasseur, G. P., and Gille, J. C.: Assimilation of satellite observations of long-lived chemical species in global chemistry transport models, J. Geophys. Res., 105, 29135-29144, 2000.

Labitzke, K. and Kunze, M.: On the remarkable Arctic winter in 2008/2009, J. Geophys. Res., 114, D00102, doi:10.1029/2009JD012273, 2009.

Lahoz W. A. and Errera, Q.: Constituent Assimilation, in Data Assimilation: Making Sense of Observations, edited by: Lahoz, W. A., Khattatov, B., and Ménard, R., Springer, 449-490, 2010.

Lahoz W. A., O’Neill, A., Carr, E. S., Harwood, R. S., Froidevaux, L., Read, W. G., Waters, J. W., Kumer, J. B., Mergenthaler, J. L., Roche, A. E., Peckham, G. E., and Swinbank, R.: Threedimensional evolution of water vapor distributions in the Northern Hemisphere stratosphere as observed by the MLS, J. Atmos. Sci., 51, 2914-2930, 1994.

Lahoz W. A., O’Neill, A., Heaps, A., Pope, V. D., Swinbank, R., Harwood, R. S., Froidevaux, L., Read, W. G., Waters, J. W., and Peckham, G. E.: Vortex dynamics and the evolution of water vapour in the stratosphere of the Southern Hemisphere, Q. J. Roy. Meteor. Soc., 122, 423-450, 1996.

Lahoz, W. A., Geer, A. J., and O'Neill, A.: Dynamical evolution of the 2003 Southern Hemisphere stratospheric winter using Envisat trace gas observations, Q. J. Roy. Meteor. Soc., 132, 19852008, 2006.

Lahoz, W. A., Errera, Q., Swinbank, R., and Fonteyn, D.: Data assimilation of stratospheric constituents: a review, Atmos. Chem. Phys., 7, 5745-5773, doi:10.5194/acp-7-5745-2007, 2007a.

Lahoz, W. A., Geer, A. J., Bekki, S., Bormann, N., Ceccherini, S., Elbern, H., Errera, Q., Eskes, H. J., Fonteyn, D., Jackson, D. R., Khattatov, B., Marchand, M., Massart, S., Peuch, V.-H., Rharmili, S., Ridolfi, M., Segers, A., Talagrand, O., Thornton, H. E., Vik, A. F., and von Clarmann, T.: The Assimilation of En- visat data (ASSET) project, Atmos. Chem. Phys., 7, 1773-1796, doi:10.5194/acp-7-1773-2007, 2007 b.

Lahoz, W. A., Orsolini, Y. J., Geer, A. J., Choi, W., and Allen, D.: Mesosphere-stratosphere transport during southern hemisphere autumn deduced from MIPAS observations, Q. J. Roy. Meteor. Soc., 135, 681-694, 2009.

Lahoz, W. A., Khattatov, B., and Ménard, R.: Data Assimilation and Information, in Data Assimilation: Making Sense of Observations, edited by: Lahoz, W. A., Khattatov, B., and Ménard, R., Springer, 3-12, 2010.

Lambert, A., Read, W. G., Livesey, N. J., Santee, M. L., Manney, G. L., Froidevaux, L., Wu, D. L., Schwartz, M. J., Pumphrey, H. C., Jimenez, C., Nedoluha, G. E., Cofield, R. E., Cuddy, D. T., Daffer, W. H., Drouin, B. J., Fuller, R. A., Jarnot, R. F., Knosp, B. W., Pickett, H. M., Perun, V. S., Snyder, W. V., Stek, P. C., Thurstans, R. P., Wagner, P. A., Waters, J. W., Jucks, K. W., Toon, G. C., Stachnik, R. A., Bernath, P. F., Boone, C. D., Walker, K. A., Urban, J., Murtagh, D., Elkins, J. W., and Atlas, E.: Validation of the Aura Microwave Limb Sounder middle atmosphere water vapor and nitrous oxide measurements, J. Geophys. Res., 112, D24S36, doi:10.1029/2007JD008724, 2007.

Lee, J. N., Wu, D. L., Manney, G. L., Schwartz, M. J., Lambert, A., Livesey, N. J., Minschwaner, K. R., Pumphrey, H. C., and Read, W. G.: Aura Microwave Limb Sounder Observations of the Polar Middle Atmosphere: Dynamics and transport of $\mathrm{CO}$ and $\mathrm{H}_{2} \mathrm{O}$, J. Geophys. Res., 116, D05110, doi:10.1029/2010JD014608, 2011.

Livesey, N. J., Read, W. G., Lambert, A., Cofield, R. E., Cuddy, D. T., Froidevaux, L., Fuller, R. A., Jarnot, R. F., Jiang, J. H., Jiang, Y. B., Knosp, B. W., Kovalenko, L. J., Pickett, H. M., Pumphrey, H. C., Santee, M. L., Schwartz, M. J., Stek, P. C., Wagner, P. A., Waters, J. W., and Wu, D. L.: Earth Observing System (EOS) Aura Microwave Limb Sounder (MLS) Version 2.2 Level 2 data quality and description document, JPL D33509, Jet Propulsion Laboratory, California Institute of Technology, Pasadena, California 91109-8099, available at: http: //mls.jpl.nasa.gov/data/v2-2_data_quality_document.pdf, 2007.

McCormack, J. P., Hoppel, K. W., and Siskind, D. E.: Parameterization of middle atmospheric water vapor photochemistry for high-altitude NWP and data assimilation, Atmos. Chem. Phys., 8, 7519-7532, doi:10.5194/acp-8-7519-2008, 2008.

Manney, G. L., Zurek, R. W., O’Neill, A., and Swinbank, R.: On the Motion of Air through the Stratospheric Polar Vortex, J. Atmos. Sci., 51, 2973-2994, 1994.

Manney G. L., Santee, M. L., Livesey, N. J., Froidevaux, L., Read, W. G., Pumphrey, H. C., Waters, J. W., and Pawson, S.: EOS Microwave Limb Sounder observations of the Antarctic polar vortex breakup in 2004, Geophys. Res. Lett., 32, L12811, doi:10.1029/2005GL022823, 2005.

Manney, G. L., Daffer, W. H., Zawodny, J. M., Bernath, P. F., Hoppel, K. W., Walker, K. A., Knosp, B. W., Boone, C., Remsberg, E. E., Santee, M. L., Harvey, V. L., Pawson, S., Jackson, D. R., Deaver, L., McElroy, C. T., McLinden, C. A., Drummond, J. R., Pumphrey, H. C., Lambert, A., Schwartz, M. J., Froidevaux, L., McLeod, S., Takacs, L. L., Suarez, M. J., Trepte, C. R., Cuddy, D. C., Livesey, N. J., Harwood, R. S., and Waters, J. W.: Solar occultation satellite data and derived meteorological products: Sampling issues and comparisons with Aura Microwave Limb Sounder, J. Geophys. Res., 112, D24S50, doi:10.1029/2007JD008709, 2007. 
Manney, G. L., Harwood, R. S., MacKenzie, I. A., Minschwaner, K., Allen, D. R., Santee, M. L., Walker, K. A., Hegglin, M. I., Lambert, A., Pumphrey, H. C., Bernath, P. F., Boone, C. D., Schwartz, M. J., Livesey, N. J., Daffer, W. H., and Fuller, R. A.: Satellite observations and modeling of transport in the upper troposphere through the lower mesosphere during the 2006 major stratospheric sudden warming, Atmos. Chem. Phys., 9, 47754795, doi:10.5194/acp-9-4775-2009, 2009a.

Manney, G. L., Schwartz, M. J., Krüger, K., Santee, M. L., Pawson, S., Lee, J. N., Daffer, W. H., Fuller, R. A., and Livesey, N. J.: Aura Microwave Limb Sounder Observations of Dynamics and Transport During the Record-breaking 2009 Arctic Stratospheric Major Warming, Geophys. Res. Lett., 36, L12815, doi:10.1029/2009GL038586, 2009b.

Mechoso, C. R., O’Neill, A., Pope, V. D., and Farrara, J. D.: A study of the stratospheric final warming of 1982 in the southern hemisphere, Q. J. Roy. Meteor. Soc., 114, 1365-1384, 1988.

Pumphrey, H. C., Filipiak, M. J., Livesey, N. J., Schwartz, M. J., Boone, C., Walker, K. A., Bernath, P., Ricaud, P., Barret, B., Clerbaux, C., Jarnot, R. F., Manney, G. L., and Waters, J. W.: Validation of middle-atmosphere carbon monoxide retrievals from the Microwave Limb Sounder on Aura, J. Geophys. Res., 112, D24S38, doi:10.1029/2007JD008723, 2007.
Rösevall, J. D., Murtagh, D. P., Urban, J., Feng, W., Eriksson, P., and Brohede, S.: A study of ozone depletion in the 2004/2005 Arctic winter based on data from ODIN/SMR and Aura/MLS, J. Geophys. Res., 113, D13301, doi:10.1029/2007JD009560, 2008.

Simmons A. J., Hortal, M., Kelly, G., McNally, A., Untch, A., and Uppala, S.: ECMWF analyses and forecasts of stratospheric winter polar vortex breakup: September 2002 in the Southern Hemisphere and related events, J. Atmos. Sci., 62, 668-689, 2005.

Strahan, S. E. and Polansky, B. C.: Meteorological implementation issues in chemistry and transport models, Atmos. Chem. Phys., 6, 2895-2910, doi:10.5194/acp-6-2895-2006, 2006.

Thornton, H. E., Jackson, D. R., Bekki, S., Bormann, N., Errera, Q., Geer, A. J., Lahoz, W. A., and Rharmili, S.: The ASSET intercomparison of stratosphere and lower mesosphere humidity analyses, Atmos. Chem. Phys., 9, 995-1016, doi:10.5194/acp-9995-2009, 2009.

Viscardy, S., Errera, Q., Christophe, Y., Chabrillat, S., and Lambert, J.-C.: Evaluation of ozone analyses from UARS MLS assimilation by BASCOE between 1992 and 1999, IEEE Journal of Selected Topics in Applied Earth Observations and Remote Sensing, 3, 190-202, doi:10.1109/JSTARS.2010.2040463, 2010.

WMO: Scientific Assessment of stratospheric ozone depletion: 2006, U.N. Environmental Programme, Geneva, Switzerland, 2007. 